\title{
RISK MANAGEMENT AND BANKING PERFORMANCE WITH CORPORATE GOVERNANCE AS MODERATING VARIABLE
}

\author{
Santi Hikmawati ${ }^{1}$ Sutrisno $^{2}$
}

Article history:

Submitted:

7 Agustus 2021

Revised:

29 Agustus 2021

Accepted:

30 Agustus 2021

\section{Keywords:}

Risk Management;

Financial Performance;

Corporate Governance;

Firm Size.

\section{Kata Kunci:}

Manajemen Risiko;

Kinerja Keuangan;

Corporate Governance;

Ukuran Perusahaan.

\section{Koresponding:}

Universitas Islam Indonesia, Yogyakarta, Indonesia

Email: sutrisno@uii.ac.id

\section{Abstract}

This research aims to analyze the effect of risk management on bank financial performance with corporate governance as a moderating variable. The independent variables used in this research are risk management, consist of credit risk (NPL), liquidity risk (LDR), and operating risk (OEIR). The dependent variable used is financial performance (ROA). Meanwhile, corporate governance as a moderating variable and firm size as a control variable. The regression model used are multiple linear regression analysis and moderated regression analysis. The sample was selected through purposive sampling method and 43 banks were selected as research sample. The result of this research showed that NPL and OEIR have a negative and significant impact on financial performance. Meanwhile, LDR has not significant effect on financial performance. Corporate governance was able to moderate the relationship between NPL and OEIR on financial performance, but unable to moderate the relationship between LDR on financial performance.

\begin{tabular}{l} 
Abstrak \\
\hline Penelitian ini bertujuan menganalisis pengaruh manajemen risiko terhadap \\
kinerja keuangan bank dengan Good Corporste Governance sebagai variabel \\
moderasinya. Variabel independen yang digunakan dalam penelitian ini \\
yakni manajemen risiko yang terdiri dari risiko kredit, risiko likuidtas, dan \\
risiko biaya operasi. Variabel dependen dalam penelitiann adalah kinerja \\
keuangan. Sedangkan Good Corporste Governance sebagai variabel \\
moderasi dan ukuran perusahaan sebagai variabel kontrol. Model regresi \\
yang digunakan adalah analisis regresi linier berganda dan analisis regresi \\
moderasi. Pemilihan sampel melalui metode purposive sampling dan 43 \\
bank terpilih sebagai sampel penelitian. Hasil dari penelitian ini \\
menunjukkan bahwa risiko kredit yang diukur dengan NPL dan risiko \\
operasional yang diukur dengan BOPO berpengurh negatif dan signifikan \\
terhadap kinerja keuangan. Sedangkan risiko likuiditas yang diukur dengan \\
LDR tidak berpengaruh terhadap kinerja keuangan. Good Corporate \\
Governance mampu memoderasi hubungan antara NPL dan BOPO terhadap \\
kinerja keuangan, namun GCG tidak mampu memoderasi hubungan antara \\
LDR terhadap kinerja keuangan.
\end{tabular}

Universitas Islam Indonesia, Yogyakarta, Indonesia $^{1}$ 


\section{INTRODUCTION}

In this era of globalization, competition between companies is very tight, change is very fast, and uncertainty is very high. Increasingly tighter competition has made many companies competing to be able to improve their company performance. The company improves its performance in order to achieve company goals and maintain the company's survival. Where the main objective of the company, including the bank, is to increase the value of the company, maximize profits for the welfare of shareholders, improve the welfare of its stakeholders and maintain the welfare of the community as a corporate social responsibility.

Factors that can be used to determine the effectiveness and efficiency of an organization in achieving its company goals are by assessing the company's performance (Bidhari et al., 2013). According to Soares \& Yunanto (2018), through assessment and analysis of financial performance, companies will obtain information about their financial position and past financial performance. Efforts to improve performance that companies can do are through the implementation of risk management and good corporate governance mechanisms (Cahyaningtyas \& Sasanti, 2019).

Risk management is a series of methodologies and procedures used to identify, measure, monitor and control risks arising from all bank business activities (POJK Number 18 / POJK.03 / 2016). Risk management is needed by companies in line with increasing competition and the complexity of the external environment that brings various opportunities and threats for the company. There are eight risks that need to be managed by banks, including credit risk, market risk, liquidity risk, operational risk, compliance risk, legal risk, reputation risk, and strategic risk (POJK Number 18 / POJK.03 / 2016).

Credit risk can be analyzed through the NPL ratio. According to research conducted by Fadun \& Oye (2020) NPL has a negative and significant effect on financial performance. On the other hand, research by Aruwa \& Musa (2014) shows that NPL has a positive and significant effect on ROA. Liquidity risk can be analyzed using the LDR ratio. According to research conducted by Kusmayadi (2018) LDR has a positive effect on ROA. Meanwhile, research by AlRdaydeh et al., (2017) shows that liquidity risk has a negative effect on ROA. Operational risk can be analyzed through the OEIR ratio. According to research conducted by Widajatun \& Ichsani (2019) OEIR has a negative and significant effect on ROA. In contrast to research conducted by Onsongo et al., (2020) where the results of OEIR have a positive effect on ROA.

Efforts that companies can do to improve performance in addition to using risk management are by implementing corporate governance mechanisms. According to Cahyaningtyas \& Sasanti (2019), the implementation of corporate governance in companies is considered very important to improve performance, maintain company image, and it is hoped that through this mechanism every company is able to face any challenges from externals, and for the creation of a more transparent company 
management for stakeholders. Many studies have been conducted on the analysis of the effect of good corporate governance in moderating the relationship between risk management and financial performance. Research conducted by Laeli \& Yulianto (2016) shows that GCG can moderate the relationship between NPF and FDR on ROA. Meanwhile, the research of Izdihar et al., (2017) shows that GCG is only able to moderate the relationship between NPL and ROA, but cannot moderate the relationship between LDR and OEIR on ROA. Akbar \& Lanjarsih (2019) shows that GCG is only able to moderate OEIR against ROA, but is unable to moderate the relationship between NPL and LDR on ROA.

This difference in results indicates a research gap, which means that there is no clear relationship between credit risk, liquidity risk and operational risk on financial performance and the ability of corporate governance to moderate the relationship between risk and financial performance. This inconsistent research result creates opportunities for further research, which is my reason for doing this research.

Company performance is a description of the company's financial condition which is analyzed with financial analysis tools, so that it can be seen about the good and bad financial condition of a company that reflects the work performance in a certain period. In general, the bank's financial performance describes the bank's achievements in carrying out business activities and its objectives (Cahyaningtyas \& Sasanti, 2019). Meanwhile, according to Sutrisno (2007:212) financial ratios are used to determine company profits. Profits obtained by a company can be assessed from its profitability ratio, namely the ROA ratio (Sutrisno, 2007:213).

Risk is the possibility of obtaining a loss as a result of a certain event. The point is that there is a possibility that an unwanted result will occur and can cause losses if it is not properly anticipated and managed (Rustam, 2018: 5). Risk management is a collection of methodologies and procedures used to identify, measure, monitor, and control risks arising from all bank business activities, including credit risk, market risk, liquidity risk, operational risk and other risks in the company's efforts to increase and maximizing the value of the company (Rustam, 2018: 12).

According to the Indonesian Bankers Association (2015:8), credit risk is the result of the failure of the debtor or other party to meet the obligation to pay off credit at the bank. The higher the bank faces credit risk, the higher the bank will experience a financial crisis, and vice versa (Gadzo et al., 2019). Credit risk, which is proxied by NPL (nonperforming loans), indicates a condition in which customers are unable to pay part or all of their loans to the bank (Soares \& Yunanto, 2018). Research conducted by Yudha et al., (2017); Buchory (2015) results show that credit risk proxied by NPL has a negative effect on financial performance.

$\mathrm{H}_{1}$ : Credit risk (NPL) has a negative effect on bank financial performance.

Liquidity risk is a risk due to the inability of the Bank to meet maturing obligations originating from cash flow funding or from high quality collateralized 
liquid assets without disrupting the Bank's activities and financial condition (POJK Number 18 / POJK.03 / 2016). Liquidity risk management is complex, this is because most of the funds managed by the bank come from short-term public funds so they can be withdrawn at any time (Cahyaningtyas \& Sasanti, 2019). Liquidity risk, which is proxied by LDR (loan to deposit ratio), indicates the ability of banks to channel their funds into credit (Widajatun, 2019). Research conducted by Siregar et al., (2019); Fadun \& Oye (2020) shows that LDR has a positive effect on bank financial performance.

$\mathrm{H}_{2}$ : Liquidity risk (LDR) has a positive effect on bank financial performance.

Operational risk is the risk that results from the inadequacy or malfunction of an internal process, human error, system failure, or caused by external events that affect the operations of the Bank (POJK Number 18 / POJK.03 / 2016). Operational risk is known to cause financial loss directly or indirectly to the company. Operational risk, which is proxied by OEIR, indicates the efficiency ratio of the bank which is used to measure the ability of bank management to manage operating costs against operating income (Kusmayadi, 2018). Research conducted by Kusmayadi (2018); Saiful \& Ayu (2019) shows that OEIR has a negative effect on ROA.

$\mathrm{H}_{3}$ : Operating risik (OEIR) has a negative effect on bank financial performance (ROA).

Corporate governance creates a structure that helps the company set goals, manage daily business activities, pay attention to stakeholder needs, ensure the company runs safely and healthily, comply with laws and regulations, and protect customer interests (Rustam, 2018: 294). The implementation of GCG can increase operational effectiveness, minimize differences in interests, and create synergies between supervisory activities and strategies that can reduce scandals, chaos and internal corruption (Bastomi et al., 2017). Banks that implement risk management accompanied by the application of GCG principles can minimize all risks and losses that may be faced. The point is that risks that have a bad impact on the health of the Bank can be minimized by implementing GCG in the Bank (Chaniago \& Widyantoro, 2017). Research conducted by Laeli \& Yulianto (2016) shows that GCG is able to moderate the relationship between NPL and LDR on financial performance. Meanwhile, research conducted by Akbar \& Lanjarsih (2019); Mardiana et al., (2018) showed that GCG was able to moderate the relationship between OEIR to bank financial performance.

$\mathrm{H}_{4}$ : GCG is able to moderate the relationship between NPL and financial performance $\mathrm{H}_{5}$ : GCG is able to moderate the relationship between LDR and financial performance $\mathrm{H}_{6}$ : GCG is able to moderate the relationship between OEIR and financial performance

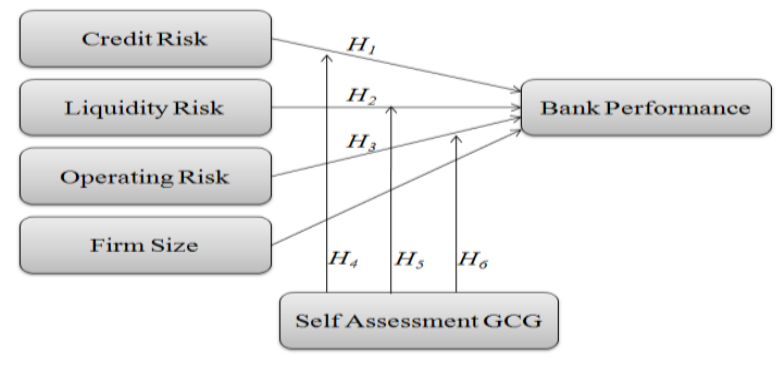

Figure 1. Reserch Concept Framework 
Based on the background, study of theories and hypotheses, a conceptual framework for the research can be made as shown in Figure 1.

\section{RESEARCH METHODS}

The population in this study were all banks listed on the Indonesia Stock Exchange. The time period used is the 20172019 period. The sampling method used in this study was purposive sampling. The requirements for sampling are banks that are listed on the IDX, have annual reports for the 2017-2019 period, and annual reports provide information on the composite values of GCG Self Assessment, ROA, NPL, LDR, OEIR and company assets. Based on the data obtained, it shows that the bank entities that are listed on the Indonesia Stock Exchange and meet the requirements to be the sample in this study are 43 banks.

In this study, using ROA as the dependent variable, NPL, LDR, and OEIR as independent variables, GCG Self Assessment as a moderating variable, and company size as a control variable. The following is a table of variables used in research and how to measure them:

Table 1.

\section{Variables and Measurement}

\begin{tabular}{ll}
\hline \multicolumn{1}{c}{ Variable } & \multicolumn{1}{c}{ Pengukuran } \\
\hline Financial Performance & EAT/Total Assets \\
Non Performing Loan & Non perform loan/Total Loan \\
Loan ti Deposit Ratio & Total Loan/Third Party Fund \\
Operating Expenses to & Operating \\
Income Ratio (OEIR) & Expenses/Operating Income \\
$\begin{array}{l}\text { Good Corporate } \\
\text { Governance }\end{array}$ & Rank of Self Assessment GCG \\
Firm Size (SIZE) & Ln Total Assets \\
\hline
\end{tabular}

The analytical tool used to test the hypothesis is using multiple linear regression analysis and moderated regression analysis. According to Ghozali (2005:81) multiple linear regression analysis is used to determine whether or not there is an influence or relationship between the independent variable and the dependent variable. The regression equation is as follows:

$\mathrm{ROA}=\alpha+\beta 1 \mathrm{NPL}+\beta 2 \mathrm{LDR}+\beta 3 \mathrm{OEIR}+$ $\beta 4 \mathrm{SIZE}+\varepsilon$.

Meanwhile, the Interaction Test or Moderated Regression Analysis is a special application of multiple linear regression in which the regression equation contains an element of interaction, also known as the multiplication of two or more independent variables (Ghozali, 2005: 150). The regression equation is as follows:

$\mathrm{ROA}=\alpha+\beta 1 \mathrm{NPL}+\beta 2 \mathrm{LDR}+\beta 3 \mathrm{OEIR}+$ $\beta 4 \mathrm{GCG}+\varepsilon$.

\section{RESULTS AND DISCUSSION}

Descriptive statistical analysis is used to describe the research variables. In descriptive statistical analysis, information about the lowest value, highest value, average, and standard deviation is known.

Table 2.

Descriptive Statistics

\begin{tabular}{llrrrr}
\hline & & & & & \multicolumn{1}{c}{$\begin{array}{c}\text { Std. } \\
\text { Deviation }\end{array}$} \\
\hline NPL & 129 & 0.06 & 15.75 & 3.6877 & 2.40412 \\
LDR & 129 & 47.54 & 163.1 & 87.6188 & 16.63889 \\
OEIR & 129 & 58.1 & 258.09 & 92.8501 & 26.52783 \\
GCG & 129 & 1.00 & 3.00 & 2.1163 & 0.46145 \\
ROA & 129 & -15.89 & 13.6 & 0.9808 & 3.09671 \\
Size & 129 & 27.223 & 34.887 & $3.12 \mathrm{E}+01$ & 1.786443 \\
\hline
\end{tabular}

Source: Data Processed, 2021 
The $\mathrm{t}$ statistical test is used in this study to determine how much influence the independent variables individually have in explaining the variation of the dependent variable. So that the $\mathrm{t}$ test can be used to determine whether or not there is a significant influence on the dependent variable.

Table 3.

Hypothesis Test Result Model 1

\begin{tabular}{|c|c|c|c|c|c|}
\hline & & \multicolumn{2}{|c|}{$\begin{array}{l}\text { Unstandardized } \\
\text { Coefficients }\end{array}$} & \multirow[b]{3}{*}{$\mathrm{t}$} & \multirow[b]{3}{*}{ Sig. } \\
\hline & & & Std. & & \\
\hline & & B & Error & & \\
\hline \multirow[t]{5}{*}{1} & (Constant) & -0.804 & 1.376 & -0.584 & 0.56 \\
\hline & NPL & -0.122 & 0.039 & -3.167 & 0.002 \\
\hline & LDR & 0.003 & 0.004 & 0.753 & 0.453 \\
\hline & OEIR & -0.054 & 0.005 & -11.404 & 0.000 \\
\hline & SIZE & 0.221 & 0.036 & 6.077 & 0.000 \\
\hline
\end{tabular}

Source: Data Processed, 2021

The results of the hypothesis testing using the $t$ test show that the NPL regression coefficient is -0.122 and a significance value of 0.002 . These results indicate that NPL has a negative and significant effect on bank financial performance. The first hypothesis is accepted. Non-Performing Loan is the ratio between the number of non-performing loans (substandard credit, doubtful credit, and bad credit) and the total credit extended by the bank. A high NPL ratio reflects the poor quality of bank credit. The higher the NPL ratio, the more bad credit the bank bears. Increasing bad credit will disrupt the turnover of working capital which in turn can reduce profits or reduce the financial performance of the bank. The results of this study are in accordance with research conducted by Fadun \& Oye (2020); Gadzo et al., (2019); Kaaya \& Pastory (2013); Widajatun \& Ichsani (2019), namely that credit risk proxied by NPL has a negative effect. to the bank's financial performance.

The results of hypothesis testing using the $\mathrm{t}$ test show that the LDR regression coefficient is 0.003 and a significance value of 0.453 . These results indicate that the LDR has a positive but insignificant effect on bank financial performance. The second hypothesis is rejected. The positive effect shows that the higher the LDR ratio indicates the bank is able to channel their funds well and will have an effect on the higher the bank's profit and performance. However, if seen from the significance value, the effect of LDR on ROA is not significant. This can occur because in obtaining profit not only pay attention to the amount or quantity of funds channeled in credit, but also pay attention to the quality of credit extended. If the amount of credit extended by the bank is large, but the payment for the credit is problematic, it will cause losses for the bank itself. Banks cannot utilize their funds effectively and cannot obtain maximum profit. The results of this study are in accordance with research conducted by Dewi et al., (2016); Kusmayadi (2018); Rusdiyanto et al., (2018); Widajatun \& Ichsani (2019), namely liquidity risk proxied by an influential LDR. positive but not significant to the bank's financial performance.

The results of hypothesis testing using the $\mathrm{t}$ test show that the OEIR regression coefficient is -0.054 and a significance value of 0.000. These results indicate that OEIR has a negative and significant effect on bank financial performance. The third hypothesis is accepted. The OEIR ratio indicates the 
efficiency of a bank in managing its operating costs against operating income. The higher the OEIR ratio indicates the poor efficiency of the bank in managing its operational costs. So that the higher operational costs can reduce the profit earned by the bank which then has an impact on the decline in the bank's financial performance. The results of this study are consistent with research conducted by Buchory (2015); Fadun \& Oye (2020); Kusmayadi (2018); Widajatun \& Ichsani (2019), namely that operational risk proxied by OEIR has a negative effect on bank financial performance.

Table 4.

Hypothesis Result Model 2

\begin{tabular}{|c|c|c|c|c|c|}
\hline & & \multicolumn{2}{|c|}{$\begin{array}{c}\text { Unstandardized } \\
\text { Coefficients } \\
\end{array}$} & \multirow[b]{2}{*}{$\mathrm{t}$} & \multirow[b]{2}{*}{ Sig. } \\
\hline & & $\mathrm{B}$ & Std. Error & & \\
\hline \multirow[t]{5}{*}{1} & (Constant) & 7.511 & 0.604 & 12.435 & 0.000 \\
\hline & NPL & -0.110 & 0.044 & -2.519 & 0.013 \\
\hline & LDR & 0.005 & 0.005 & 1.044 & 0.299 \\
\hline & OEIR & -0.063 & 0.005 & -12.383 & 0.000 \\
\hline & GCG & -0.385 & 0.156 & -2.473 & 0.015 \\
\hline
\end{tabular}

Source: Data Processed, 2021

The results of hypothesis testing using the $t$ test show that the regression coefficient is -0.110 and a significance value of 0.013 . These results indicate that NPL has a negative and significant effect on bank financial performance as moderated by the GCG variable. The fourth hypothesis is accepted. The implementation of GCG at banks can indirectly minimize the increase in NPL ratios and can affect the increase in bank financial performance. The better the moderate GCG rating, the lower the level of bad credit and improve the bank's financial performance, which is reflected in the increase in the ROA ratio and vice versa. The results of this study are consistent with research conducted by Laeli \& Yulianto (2016); Izdihar et al., (2017) which show that good corporate governance is able to moderate the relationship between proxied credit risk and NPL on bank financial performance.

The results of hypothesis testing using the $t$ test show that the regression coefficient is 0.005 and a significance value of 0.299. These results indicate that the LDR has a positive but insignificant effect on bank financial performance as moderated by the GCG variable. The fifth hypothesis is rejected. The positive effect shows that the better the moderating GCG rating, the better the bank's liquidity and the bank's financial performance. However, if seen from the significance value, it shows that the effect of GCG in moderating the relationship between LDR and ROA is not significant. This can occur because according to Bank Indonesia Regulation (PBI No. 17/11 / PBI / 2015) the limit for the amount of the LDR ratio for commercial banks is $78-92 \%$, while in the study sample there is still an LDR ratio that is below $78 \%$. Based on these results, it shows that there are still banks in the sample that have not been able to channel their funds effectively and their credit quality is not yet good. This indicates that the implementation of GCG in banks has not been able to moderate the relationship between liquidity risk as proxied by LDR on financial performance. The results of this study are consistent with research conducted by Akbar \& Lanjarsih (2019); Izdihar et al., (2017); Bangun \& Bakar (2018) which show that 
good corporate governance is unable to moderate the relationship between liquidity risk proxied by LDR. to the bank's financial performance.

The results of hypothesis testing using the $\mathrm{t}$ test indicate that the regression coefficient is -0.063 and a significance value of 0.000 . These results indicate that OEIR has a negative and significant effect on bank financial performance as moderated by the GCG variable. The sixth hypothesis is accepted. The implementation of GCG Self Assessment at banks can indirectly minimize the increase in the OEIR ratio and can affect the increase in bank financial performance. The better the moderate GCG rating, the less operating expenses, managing operating expenses efficiently, and improving the bank's financial performance, which is reflected in the increase in the ROA ratio and vice versa. The results of this study are consistent with research conducted by Akbar \& Lanjarsih (2019); Mardiana et al., (2018) showing that good corporate governance is able to moderate the relationship between operational risk proxied by OEIR on financial performance.

\section{CONCLUSSION AND SUGGESTION}

Based on the analysis and discussion of risk management on banking financial performance with GCG Self Assessment as a moderating variable, it can be concluded that credit risk which is proxied by NPL (Non Performing Loan) has a negative and significant effect on financial performance (ROA). Liquidity risk, which is proxied by
LDR (Loan to Deposit Ratio), has a positive but insignificant effect on financial performance (ROA). Operational risk which is proxied by OEIR (Operational Cost to Operating Income) has a negative and significant effect on financial performance as proxied by ROA. Credit risk which is proxied by NPL (Non Performing Loan) has a negative and significant effect on financial performance as proxied by ROA. Liquidity risk, which is proxied by LDR (Loan to Deposit Ratio), has a positive but insignificant effect on financial performance as moderated by GCG Self Assessment. Operational risk which is proxied by OEIR (Operational Cost to Operating Income) has a negative and significant effect on financial performance which is moderated by GCG Self Assessment.

The following research limitations are obtained: (1) the research carried out only includes banks listed on the IDX with a time period of three years, namely 2017-2019, it is hoped that further research can increase the number of samples and the time period of the study. (2) The results of the determination coefficient test (adjusted $\mathrm{R}^{2}$ ) are not maximal, so there are other variables that can explain the effect of risk management on financial performance. It is hoped that further research can add variables that are not in the study. (3) Liquidity risk calculated using the LDR ratio has not had a significant effect. It is hoped that further research can use other liquidity ratios to obtain different results. (4) GCG assessment used in this study uses GCG selfassessment. In order to increase objectivity, it is hoped that further research can use GCG assessments from other parties. 
Risk Management and Banking Performance...

Santi Hikmawati \& Sutrisno

\section{REFERENCES}

Akbar, T., \& Lanjarsih, L. (2019). Pengaruh Corporate Governance sebagai Variabel yang Memoderasi Kinerja Profitabilitas Bank. Journal Proceeding of National Conference on Accounting and Finance, 1, 9-21. https://journal.uii.ac.id/NCAF/article/view/13 813

Al-Rdaydeh, M., Matar, A., \& Alghzwai, O. (2017). Analyzing the Effect of Credit and Liquiditty Risk on Profitability of Conventional and Islamic Jordanian Bank. International Journal of Academic Reseacrch in Business and Social Sciences, $\quad 7(12), \quad$ 1145-1155. https://www.researchgate.net/publication/323 119648_Analyzing_the_Effect_of_Credit_and _Liquidity_Risks_on_Profitability_of_Conve ntional_and_Islamic_Jordanian_Banks

Aruwa, S. A. S., \& Musa, A. O. (2014). Risk Component and the Financial Performance of Deposit Money Bank in Nigeria. International Journal of Social Science and Enterpreneurship, $\quad 1(11), \quad 1-8$. https://www.academia.edu/15488506/RISK_C OMPONENTS_AND_THE_FINANCIAL_P ERFORMANCE_OF_DEPOSIT_MONEY_B ANKS_IN_NIGERIA

Bangun, Y. F. B., \& Bakar, E. A. (2018). The Influence of Profitability, Liquidity, Leverage, and Activity Ratio on Profit Growth with Managerial Ownership as Moderating Variable at Automotive and Component Company Listed in the Indonesia Stock Exchance. International Journal of Public Budgeting, Accounting, and Finance. 1(4): 111. https://garuda.ristekbrin.go.id/documents /detail/876877

Bastomi, M., Salim, U., \& Aisjah, S. (2017). The Role of Corporate Governance and Risk Manajement on Banking Financial Performance in Indonesia. Jurnal Keuangan dan Perbankan, 21(4), 670-680. https://doi.org/10.26905/jkdp.v21i4.1285

Bidhari, S.C., Salim, U., \& Aisjah, S. (2013). Effect of Corporate Social Responsibility Information Disclosure on Financial Performance and Firm Value in Banking Industry Listed at Indonesia Stock Exchange. European Journal of Business and Management, 5(18), 39-46. https://core.ac.uk/download/pdf/234624881.p df
Buchory, H. A. (2015). Bank Profitability: How Does the Credit Risk and Operationa; Efficieny Effect?. Journal of Business and Management Sciences, $\quad 3(4), \quad 118-123$. https://citeseerx.ist.psu.edu/messages/downloa dsexceeded.html

Cahyaningtyas, S. R., \& Sasanti, E. E. (2019). Penerapan Manajemen Resiko Bank, Tata Kelola Perusahaan, dan Kinerja Perusahaan Perbankan Indonesia. Jurnal Aplikasi Akuntansi, $\quad 3(2), \quad$ 170-206. https://doi.org/10.29303/jaa.v3i2.52

Chaniago, H., \& Widyantoro, H. (2017). RBBR Model: A Prediction Model of Bank Health Level Based on Risk for Regional Development Banks (BPD) in Indonesia. Journal of Economics, Business, and Accountancy Ventura, 20(1), 47-60. https://doi.org/10.14414/jebav.v20i1.1064

Dewi, F. S., Arifati, R., \& Andini, R. (2016). Analysis of Effect of CAR, ROA, LDR, Company Size, and GCG to Bank Profitablity (Case Study in Banking Companies Listed in BEI Period 2010-2013). Journal of Accounting, 2(2), 117. http://jurnal.unpand.ac.id/index.php/AKS/ article/view/465/451

Fadun, O. S., \& Oye, D. (2020). Impacts of Operational Risk Management on Financial Performance: A Case of Commercial Bank in Nigeria. International Journal of Finance and Banking Studies, 9(1), 22-35. https://www.academia.edu/44840464/Impacts _of_Operational_Risk_Management_on_Fina ncial_Performance_A_Case_of_Commercial_ Banks_in_Nigeria

Gadzo, S. G., Kportorgbi, H. K., \& Gatsi, J. G. (2019). Credit Risk and Operational Risk on Financial Performance of Universal Bank in Ghana: A Partial Least Squared Structural Equation Model (PLS SEM) Approach. Cogent Economic and Finance. 7(1), 1-16. https://doi.org/10.1080/23322039.2019.15894 06

Ghozali, I. (2005). Aplikasi Analisis Multivariate Dengan Program SPSS. Semarang: Badan Penerbit UNDIP.

Ikatan Bankir Indonesia. (2015). Manajemen Risiko 1: Mengidentifikasi Risiko Pasar, Operasional, dan Kredit. Jakarta Pusat: Gramedia.

Izdihar, S., Hasan, A., \& Azlina, N. (2017). Pengaruh Penerapan Manajemen Risiko Terhadap Kinerja Keuangan dengan Dimoderasi Good Corporate Governance (Studi EMpiris pada 
Risk Management and Banking Performance...

Santi Hikmawati \& Sutrisno

BPD Se-Indonesia Tahun 2009-2013). Jurnal Ekonomi, 25(2), 71-88. https://je.ejournal.unri.ac.id/index.php/JE/artic le/view/6044/5562

Kaaya, I., \& Pastory, D. (2013). Credit Risk and Commercial Banks Performance in Tanzania: a Panel Data Analysis. Journal of Finance and Accounting, 4(16), 55-62. https://core.ac.uk/download/pdf/234629658.p df

Kusmayadi, D. (2018). Analysis of Effect of Capital Adequacy Ratio, Loan to Deposit Ratio, NonPerforming Loan, BOPO, and Size On Return On Assets In Rural Bank at Indonesia. Saudi Journal of Business and Management Studies, $3(7)$, 786-795. https://www.semanticscholar.org/paper/Analy sis-of-Effect-of-Capital-Adequacy-Ratio\%2CLoan-Kusmayadi/80c29df8605959c402622a d3520a23e48915e9c6

Laeli, A., \& Yulianto, A. (2016). The Effect of Financial Health on Profitability with Islamic Corporate Governance as a Moderating Variable. Accounting Analysis Journal, 5(3), 163-172. https://journal.unnes.ac.id/sju/index. php/aaj/article/view/11197

Mardiana, Endah, P., \& Dianata, A. W. M. (2018). The Effect of Risk Management on Financial Performance with Good Corportae Governance as a Moderation Variable. Management and Economics Journal, 2(3), 257-268. http://ejournal.uin-malang.ac.id/ index.php/mec/article/view/5223/pdf

Onsongo, S. K., Muathe, S. M. A., \& Mwangi, L. W. (2020). Financial Risk and Financial Performance: Evidence and Insights from Commercial and Services Listed Companies in Nairobi Securities Exchange, Kenya. International Journal of Financial Studies, $8(3), \quad 1-15$. https://www.mdpi.com/2227$7072 / 8 / 3 / 51$

Peraturan Bank Indonesia Nomor 17/11/PBI/2015 Perubahan atas Peraturan Bank Indonesia Nomor 15/15/PBI/2013 Tentang Giro Wajib Minimum Bank Umum dalam Rupiah dan Valuta Asing Bagi Bank Umum Konvensional. 26 Juni 2015. Lembaran Negara Republik Indonesia Tahun 2015 Nomor 152. Jakarta: Bank Indonesia.

Peraturan Otoritas Jasa Keuangan Nomor 18/POJK.03/2016 Penerapan Manajemen Risiko bagi Bank Umum. 22 Maret 2016. Jakarta: Lembaran Negara Republik Indonesia
Tahun 2016 Nomor 53 Otoritas Jasa Keuangan.

Rusdiyanto., Soetedjo, S., Susetyorini., \& Elan, U. (2018). The Effect of Capital Adequacy Ratio (CAR), Net Profit Margin (NPM), Return on Assets (ROA), Non-Performing Loans (NPL), and Loan to Deposit Ratio (LDR) to Stock Prices in Banking Companies on the Indonesia Stock Exchange. International Journal of Science and Research, 8(7), 14991510. https://core.ac.uk/download/pdf/2346 29658.pdf

Rustam, B. R. (2018). Manajemen Risiko. Jakarta Selatan: Penerbit Salemba Empat.

Saiful., \& Ayu, D. P. (2019). Risk Management and Bank Performance: The Empirical Evidences from Indonesian Conventional and Islamic Banks. International Journal of Economics and Financial Issue, 9(4), 90-94. https://doi.org/10.32479/ijefi.8078

Siregar, L., Lubis, A. F., \& Erwin, K. (2019). Analysis of the Effect of Financial Ratio on Banking Performance in Indonesia Stock Exchange with Stock Return as A Moderating Variable in 2013-2017. Journal of Budgeting Accounting and Finance, 2(1), 1-10. https://garuda.ristekbrin.go.id/documents/deta i1/933853

Soares, P., \& Yunanto, M. (2018). The Effect of NPL, CAR, LDR, OER, and NIM to Banking Return on Asset. International Journal of Economics, Commerce, and Management, 6(3), 40-55. http://ijecm.co.uk/wpcontent/uploads/2018/03/633.pdf

Sutrisno. (2007). Manajemen Keuangan, Teori, Konsep, dan Aplikasi. Yogyakarta: EKONISIA.

Widajatun, V. W., \& Ichsani, S. (2019). The Impact of Credit, Liquidity, Operational and Market Risk on Return on Asset. Global Business and Management Research: An International Journal, $\quad 11(1), \quad 335-340$. https://www.proquest.com/openview/27f60f6 45d995956170727c0c4e396df/1?pqorigsite $=$ gscholar \&cbl $=696409$

Yudha, A., Chabachib, \& Pangestuti, I. R. D. (2017). Analysis of the Effect of NPL, NIM, Not Interest Income, and LDR toward ROA with Size as Control Variables. Jurnal Bisnis STRATEGI, 26(2), 100-113. https://ejournal.undip.ac.id/index.php/jbs/artic le/viewFile/15175/12420 